\title{
Early Listening Skill on Lesson Study-Based Activities
}

\author{
Farida Samad ${ }^{1}{ }^{凶}$, Rosita Wondal $^{1}$, Nurhasanah ${ }^{2}$ \\ Pendidikan Guru Pendidikan Anak Usia Dini, Universitas Khairun Ternate, Indonesia(1) \\ Pendidikan Biologi, Universitas Khairun Ternate, Indonesia(2) \\ DOI: $\underline{10.31004 / o b s e s i . v 6 i 3.1895}$
}

\begin{abstract}
This study aimed to describe children's listening skills in lesson study-based learning activities at Telkom preschool group B1 in Ternate City. The students involved were 24 early students. The lesson study process included preparing, observing, and reflecting lessons in the context of listening skills. In data analysis, Miles and Huberman interaction model was employed to describe the data qualitatively and quantitative data analyzed using descriptive statistics. The results showed that children listening skill on lesson study-based learning activity on the 'market day' topic implemented at Telkom Preschool Group B1 in Ternate City was categorized as good (81.8) and sufficient (68.2). Furthermore, the data the development of a non-cognitive assessment instrument for listening ability in early childhood based on lesson study is feasible to be implemented.The result can be used as a basis for improvement and strengthening a lesson study activities dealing with listening skills in preschool that lesson study-based activities can improve children early listening skills in understanding subjects on the theme 'market day'.
\end{abstract}

Keywords: listening skill; lesson study; early childhood

\begin{abstract}
Abstrak
Penelitian ini bertujuan untuk mendeskripsikan keterampilan menyimak anak dalam kegiatan pembelajaran berbasis lesson study di PAUD Telkom kelompok B1 Kota Ternate yang berjumlah 24 siswa. Proses lesson study meliputi tahapan plan, do dan see dalam konteks keterampilan menyimak. Teknik analisis data menggunakan model interaksi Miles dan Huberman untuk mendeskripsikan data secara kualitatif dan data kuantitatif dianalisis secara statistic deskriptif. Hasil penelitian menunjukkan bahwa keterampilan menyimak siswa kelompok B pada kegiatan pembelajaran berbasis lesson study tema 'market day' di PAUD Telkom Grup termasuk pada kategori baik $(81,8)$ dan cukup $(68,2)$. Selanjutnya berdasarkan data pengembangan instrumen penilaian nonkognitif kemampuan menyimak anak usia dini berbasis lesson study layak untuk diterapkan. Hasil tersebut dapat digunakan sebagai dasar untuk perbaikan dan penguatan kegiatan lesson study yang berkaitan dengan keterampilan menyimak di lembaga PAUD yang mana kegiatan berbasis lesson study dapat meningkatkan keterampilan menyimak pada anak usia dini dalam mempelajari tema 'market day'.
\end{abstract}

Kata Kunci: kemampuan berpikir tingkat tinggi, bahasa, anak usia dini

Copyright (c) 2021 Farida Samad, et al.

$\triangle$ Corresponding author:

Email Address: faridasamad81@gmail.com (Ternate, Indonesia)

Received 29 July 2021, Accepted 12 November 2021, Published 22 November 2021 


\section{INTRODUCTION}

Language is a verbal tool used to communicate, while language is the process of delivering information in communication. Learning language is very crucial in children before 6 years Children's language development is needed to interact with humans and their environment. In language learning the four skills are important to be mastered by language learner (Spilt et al., 2015). They are complementary to one another. The listening skill is the earliest ability in life before speaking, reading and writing. Listening as one of the language skill is an important skill that develops first and that is essential in the development of other language skill. Listening skills are vital in a child's development because they allow the child to function properly in society. Listening is the process of structuring sounds and speech in the mind as a result of the hearing, focusing the attention and understanding stages (Oduolowu \& Oluwakemi, 2014; Piştav-Akmeşe et al., 2019). When developing these skills, it is important that a child become active listener, which means that he uses what he hears from others as part of the communication process. There are various ways to develop listening skills in kindergarten children, such as methods of repeating speech, listening to it, guessing, answering questions, paraphrasing, summarizing, and chain whispering. (Gilakjani \& Ahmadi, 2011). Lesson study (LS) as a model of teacher professional development has long been adopted and implemented in learning activities in Indonesia (Miharja et al., 2020; Gayatri et al., 2015; Aliah, 2014). Furthermore it was spread in Ternate collaboration between Universitas Khairun and elementary level. Telkom Preschool Ternate is one of piloting school that consistently reform learning school through lesson study. However, school reform efforts often encounter many obstacles and challenges, one of which is the lack of students' collaborative skills (Chong \& Kong, 2012)

In fact, a classroom activity at preschool is rarely carried out activities to improve listening ability. Children should be trained to do some activities involve developing language, especially listening (Reddy \& Reddy, 2011). During free time, teachers tend to fill in activities that support the development of cognitive abilities such as working on children's worksheets. In addition, teacher's method is also less varied, especially in activities that support language development so that children's listening skills are not optimal. Teachers tend to use the discussion method in the learning process carried out in class, so group work was not run optimally; only one or two students were actively engaged in the discussion. Collaborative learning, including authentic learning (which is in line with the characteristic of the materials) and relationships or interactions in learning (listen to each other) need to be developed for early childhood education (Wismath \& Orr, 2015; Samad et al., 2020). Moreover, it is important to foster the basic relationship among students to enhance their collaboration. The best practice gained from the research needed to follow up with innovative activities deal with listening skill and also habituation in strengthening young learner ability in collaborative learning.

Observations conducted in group B1 Telkom preschool Ternate City on the topic 'Market Day' with a group collaboration learning model, showing that the listening ability of children varies in each group that is divided by the teacher. This can be seen when the teacher asks questions, there are only a few children who pay attention and they are not busy when teacher is giving material. In addition, the differences in listening ability will be seen when children are asked to recount the material given. It is caused by several factors, including classrooms that are not yet supportive because they are adjacent to other classes. This caused a disturbance because the voices of other classes were heard so loud that there was a commotion. In addition, other disturbances occur in the form of the attitudes of some children who disturb other children. The disturbances that occur are inviting friends to chat, disturbing friends' views, and poking at friends who are paying attention. However, some children remain calm and try to pay attention because they already understand the material provided by the class teacher. Thus, efforts are needed to optimize collaborative learning through listening skills that can facilitate all students to learn effectively (Hamann et al., 2011; 
Collaborative for Academic Social and Emotional Learning, 2019; Hourcade et al., 2002). Unlike the previous research, this study was focused on listening activities in early childhood education. This study specifically aimed to describe children listening ability on lesson studybased learning activities on the 'market day' topic at Telkom Preschool group B1 in Ternate city.

\section{METHODOLOGY}

This is a qualitative research study to find out how children's listening skills in lesson study-based learning activities. This research is conducted at Telkom Preschool group B1 Ternate. The subjects are B1 class kindergarten students in second semester of academic year 2019/2020 with the number of 24 students, while the data were gathered from lesson study implementation (Fujie, 2019; Samad et al., 2020). The data required for the analysis included documentation data obtained from Telkom preschool group B1 in Ternate and also observation data on students activities during the learning process in classroom. The lesson study process included preparing, observing, and reflecting lessons in the context of listening skill on theme 'market day' involve four aspects namely: children skill, creativity, readiness and attitudes within listening activities. The learning cycle can be seen in Figure 1.
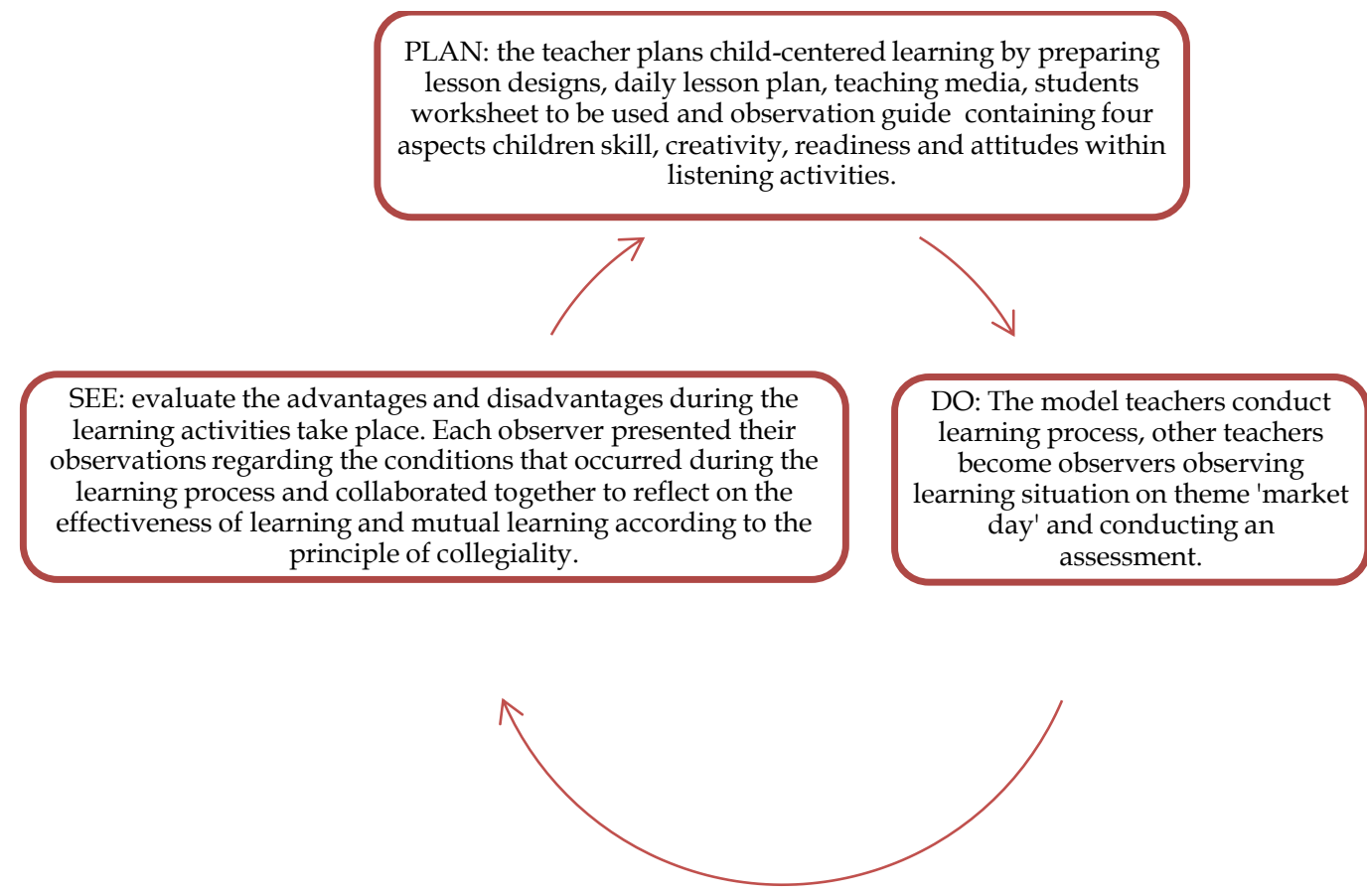

Figure 1. The learning cycle

The instruments used observation sheet, sound recording, and documentation. To analyze the data, the technique is a qualitative data analysis developed by Miles and Huberman (Huberman \& Miles, 2012; Miles et al., 2014) consisting of three stages performed sequentially those are: 1) data reduction, 2) presents data, 3) draw conclusions and verification and quantitative data will be analyzed using descriptive statistics.

\section{RESULT AND DISCUSSION}

The results of children listening skill on theme 'market day' involve four aspects namely: children skill, creativity, readiness and attitudes within listening activities. Collaborative learning occurs that the interactions of each student during the learning process on theme "market day" have been going on smoothly and as expected. Appreciation made by the model teacher during the opening activity was enough to make students enthusiastic about 
learning and begin to focus on the message conveyed by the teacher. The reinforcement of the material provided by the model teacher was able to attract children's attention to listening to the contents of the story that was conveyed by the teacher in the ongoing learning process related to the experience of going to the market. At the beginning of the learning activity, the model teacher began to divide the group with an explanation of each activity to be carried out. Students begin to pay attention quite well so that they can easily understand every play that is given, including coloring mustard greens, decorating pencil cases and collages. In group activities, some students are seen who are active and focus their attention on their teachers and friends, in addition, some participants are also less active in chatting with their friends and their attention is easily broken when their friends tease them. For those who are less active, the model teacher provides motivation to stay enthusiastic in completing their assignments. For more details, the following will discuss per indicator of children's listening ability in group B1 Telkom Preschool.

Table I Children Listening Ability On Lesson Study-Based Learning Activities

\begin{tabular}{|c|c|}
\hline Group & Children Listening Ability \\
\hline $\begin{array}{l}\text { Mango: } \\
\text { - Jag } \\
\text { - Gin } \\
\text { - Em } \\
\text { - Bag }\end{array}$ & $\begin{array}{l}\text { In the mango group, there is one student (Jag) who has very good listening skills in the aspect } \\
\text { of listening with a happy expression when telling stories about his "experience of going to the } \\
\text { market" and also he is enthusiastic about listening. When the teacher asks about his experience } \\
\text { in the market, he will immediately come to the front and share his experience in the market } \\
\text { with his mother. He was also able to name objects he had encountered in the market such as } \\
\text { fruit, fish and vegetables. Even these students often respond and respond to stories told by the } \\
\text { teacher well. Besides that, Jag also appeared to be careful in completing the activity of coloring } \\
\text { the mustard vegetable pictures, decorating the pencil case and making kolase. Jag is able to } \\
\text { collaborate well with Em, Bag and Gin. There are two students who have sufficient listening } \\
\text { ability (Em and Gin) and one student has low listening ability (Bag). When telling about the } \\
\text { experience to the market, Gin is very expressive. She is able to tell her experience to the market } \\
\text { with her mother by a motorbike. However, she did not mention the objects he encountered } \\
\text { while shopping at the market. Em is not as expressive as Gina when she responds to the } \\
\text { teacher's story. She seemed calm when telling the story with an ordinary expression. In this } \\
\text { group too, Gina has a fairly dominant listening ability in completing worksheet on coloring the } \\
\text { mustard vegetable picture. However, Gin seems selfish and doesn't want to cooperate with Em. } \\
\text { Bag has a poor listening ability. He is inattentive and unfocused when the teacher asks them to } \\
\text { tell a story. He also often teases and annoys Gi during her coloring and kolase activities. At } \\
\text { certain times Bag will help Gin to complete her coloring activities by lending her green colored } \\
\text { pencils. Bag also has a caring attitude towards Gin by asking her to remain friends with Em. }\end{array}$ \\
\hline $\begin{array}{l}\text { Waterme } \\
\text { lon: } \\
\text { - Sof } \\
\text { - Pa } \\
\text { - Vic } \\
\text { - Keys }\end{array}$ & $\begin{array}{l}\text { In the Watermelon group, there are three students who had very good listening skills (Sof, Pa } \\
\text { and Vic) and one student who had sufficient listening ability (Keys). In this group, these four } \\
\text { students listened attentively to the activities of telling stories about the 'experience of going to } \\
\text { the market' by the teacher and were able to respond and give opinions very well and also } \\
\text { actively ask questions during play activities in class. Sof told the teacher that she went to the } \\
\text { market with her brother. Sof buys tomatoes. She also mentioned shopping at the mall and } \\
\text { finding fruit and clothes at the mall. Meanwhile, Pa is very specific in telling about his } \\
\text { experiences, such as when he went to the Kota Baru market, he saw someone selling children's } \\
\text { clothes, fish sellers, yellow rice, a speed parking lot in the market and told about his experience } \\
\text { riding speed. Vic said there were durian fruit in the market and bought vegetables with his } \\
\text { mother, but he didn't really respond well to his experience. Sof and Pa have high motivation, } \\
\text { making them very careful in completing various play activities, including coloring pictures of } \\
\text { mustard greens, decorating pencil cases and making collages. Student worksheet and kolase } \\
\text { given by the teacher were able to be completed very neatly compared to other groups. Pa and } \\
\text { Sof also with good listening skills were able to explain to their friends Keys during their pasting } \\
\text { activity, where the pencil case that resembles Keys's "cat" was turned upside down and Pa } \\
\text { promptly told her to correct it. In this case, Pan is very concerned and responsible in helping } \\
\text { his friends in the group and invites them to finish playing activities together. }\end{array}$ \\
\hline
\end{tabular}

Kankung In the kankung group, there are two students with sufficient listening skills (Qe and Aq). They : are happy and enthusiastic enough to listen to the teacher when the activity tells about their 


\begin{tabular}{|c|c|}
\hline $\begin{array}{l}\text { - Qe } \\
\text { - Aq } \\
\text { - Fi } \\
\text { - Saf }\end{array}$ & $\begin{array}{l}\text { 'experience of going to the market'. They are able to respond specifically to their experiences in } \\
\text { the market and the ability to respond to stories that are starting to develop. During the question } \\
\text { and answer activities, Qe was quite active in asking questions during classroom learning } \\
\text { activities. The teacher's assistance was given to Aq during an activity to decorate the pencil case } \\
\text { because his work was upside down. There was one student who was absent due to illness (Saf) } \\
\text { and one student with poor listening ability (Fi) because she did not show a happy face during } \\
\text { the initial activity listening to the model teacher's story and was less enthusiastic so that she did } \\
\text { not understand the teacher's answer because she talked more together her friend If from other } \\
\text { group and during group activities Fi also enjoyed chatting with her friend Aq. In the activity of } \\
\text { coloring pictures of mustard greens, Qe completed her worksheet faster than Aq and Fi. }\end{array}$ \\
\hline $\begin{array}{l}\text { Spinach: } \\
\text { - If } \\
\text { - Di } \\
\text { - Han } \\
\text { Ba }\end{array}$ & $\begin{array}{l}\text { In Spinach group, there were two students with poor listening skills (If and Di) and two } \\
\text { students with poor listening skills (Han and Ba). In the aspect of activity telling stories about } \\
\text { the 'experience of going to the market', the teacher shows a picture of several types of fruit and } \\
\text { vegetables and If responds sufficiently by giving comments on what she understands, If also } \\
\text { often interferes with Dias in coloring activities and Dias often protests Ifa's opinion about her } \\
\text { behavior that. Hanna and Bagir have less motivation and enthusiasm in learning, because in } \\
\text { the activity of coloring the mustard greens, when Di started coloring her worksheet, Hanna was } \\
\text { still having fun chatting in her seat with Bagir about 'washing hands because Bagir's hands were } \\
\text { dirty', Bagir looked lacking. Independently in completing LKA for coloring and making } \\
\text { collages because she still asked the Teacher about the colors of the vegetables to be colored. This } \\
\text { group lacks accuracy in completing activities for coloring pictures of mustard greens, } \\
\text { decorating pencil cases and making collages, but the collaboration that occurs in this group is } \\
\text { good. }\end{array}$ \\
\hline $\begin{array}{l}\text { Cauliflo } \\
\text { wer : } \\
\text { - Afi } \\
\text { - Hus } \\
\text { - Ray } \\
\text { - Alf }\end{array}$ & $\begin{array}{l}\text { In Cauliflower group, there were two students with sufficient listening skills (Hus and Afi) and } \\
\text { one student who was absent (Alf). In this group, when the learning activities started, Afi paid } \\
\text { attention to the teacher's story but she did not respond well, but during coloring, decorating } \\
\text { and collage activities, Afi was patient waiting for her turn and still paid close attention to her } \\
\text { two friends in the group (Hus and Ray). Afi often ask for the teacher's opinion about her } \\
\text { assignments. Three of them began to understand the activity of telling stories about their } \\
\text { 'experience of going to the market', being less able to interpret stories and only answering } \\
\text { teacher questions. Afi only answers one or two words, for example "there is rica". The teacher } \\
\text { still has to give Ray motivation in learning because Ray is not as usual at that time. Ray looks } \\
\text { silent and daydreams a lot. When the teacher asked Ray, he would only answer with a nod of } \\
\text { his head. His worksheet deal with coloring the mustard greens neatly because of his } \\
\text { thoroughness in completing the activities to color the mustard vegetable pictures and } \\
\text { decorating the pencil case, however when making the kolase Ray was not excited, only his two } \\
\text { friends, Afi and Hus, were actively completing the kolase. }\end{array}$ \\
\hline 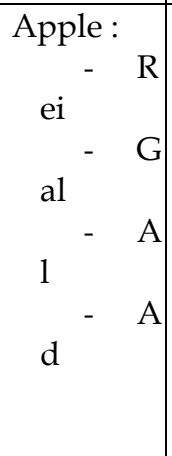 & $\begin{array}{l}\text { In apple group, most of the students had sufficient listening ability. In the aspect of listening to } \\
\text { storytelling activities about the 'experience of going to the market', (Gal) was able to respond to } \\
\text { the teacher's story but often he did not focus because he was engrossed in telling stories with } \\
\text { his friend Rei in the group. (Gal and Al) seemed cheerful and enthusiastic in playing activities } \\
\text { compared to their two friends (Rei and Ad). The four of them have the ability to ask and } \\
\text { respond to emerging stories and they are also active in answering questions given by teachers } \\
\text { about the experience. In this group, students cooperate with their closest friends in completing } \\
\text { assignments given by the teacher, it is quite different with (Ad) who has a quiet character and } \\
\text { does not like to tell stories with his three friends especially in individual activities such as } \\
\text { coloring pictures of mustard greens and decorating pencil cases. In kolase activities, he } \\
\text { collaborates with three of them in a group. }\end{array}$ \\
\hline
\end{tabular}

Table 1 indicated that there are four criteria for assessing students' listening ability in the learning process with lesson study based activities. In the criteria of very good (SB), students who have the ability to listen attentively are able to look at the teacher in the activity of telling stories about their 'experience of going to the market' with faces and mimics who are happy and also enthusiastic about listening the story until the end. Besides, the students also respond and ask questions from the stories told by the teacher so that students are able to know the meaning of new words in the story. In the sufficient criteria (C), students who have the ability to listen attentively all storytelling activities and they are very enjoyable. The students who participated in activities looked enthusiastic from the beginning to the end of 
the activities. However, there were still three children who could not carry out activities with good result until the end of the activity due to the difficulty of the children to concentrate. In less criteria (K), it appears that students who have not been able to sit quietly are moved to another group so that the teacher invites students to be active in telling stories about their 'experience of going to the market'. More students are asked to focus more because there are still some who have not been able to show the ability to listen attentively, interpret, and understand meaning (Pebriana \& Fantiro, 2017; Budyawati \& Hartanto, 2017). Thus, lesson study based- activities are quite effective in improving early childhood listening skills, although there are several obstacles. Of course, children are able to bring up behaviors that reflect listening ability even though their abilities have not been consistent and have not been shown by all children. In the activities, children often talk about various things by listening to information with their teacher and friends in class. In addition, some children reminded each other when they took actions that did not want to communicate well with the teacher. The following are the result of listening ability.

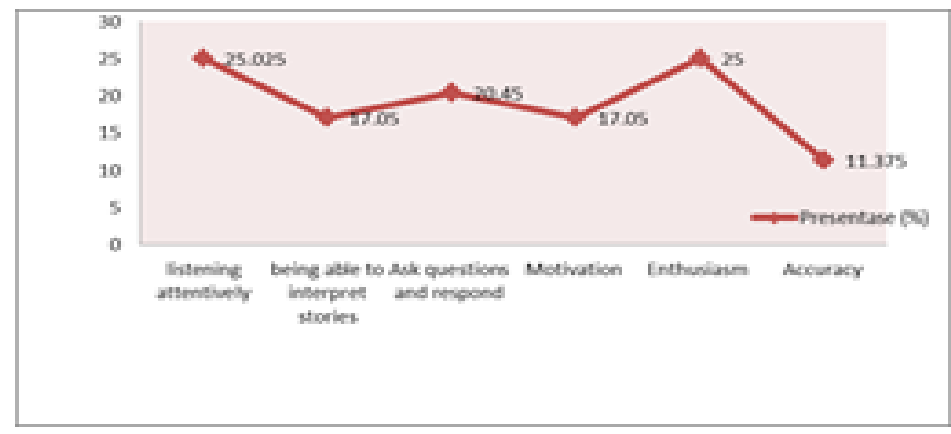

Figure 2. Result of Listening Skill and Creativity of Students

Based on the figure 2, it shows that there are 10 students or $25.02 \%$ have criteria that often appear in the aspect of listening attentively, 15 students or $17.05 \%$ have criteria that often appear in the aspects of being able to interpret stories, ask questions anmeand respond during learning activities , 18 students or $20.45 \%$ answered questions and retold them. Meanwhile, 15 students or $17.05 \%$ had criteria that often appeared in the aspects of motivation and 15 students or $25 \%$ are enthusiasm during learning activities and there were 10 students or $11.37 \%$ who had criteria that often appeared in the aspect of listening with accuracy in completing the assignments given by the teacher. From these data, it can be seen that, the average score of listening ability through on lesson study-based learning activities is in the aspect of listening attentively and enthusiastically categorized enough (Wahyuni, 2020).

Meanwhile, based on figure 2 above, it shows that there are 8 students or $7.95 \%$ have criteria always appear in the aspect of sitting quietly and not crowded during learning activities, 15 students or $17.05 \%$ have criteria that often appear in the aspect of using learning resources based on the theme, 10 students or $11.36 \%$ are able to cooperate and be disciplined in playing activities. Meanwhile, 11 students or $12.5 \%$ had criteria that often appeared in the aspect of caring for their peers during playing activities and there were 16 students or $18.18 \%$ who had criteria that often appeared in the aspect of being responsible for the assignments given during learning. From these data, the researchers concluded that the aspect of being responsible for the tasks given during the learning process was sufficient. 


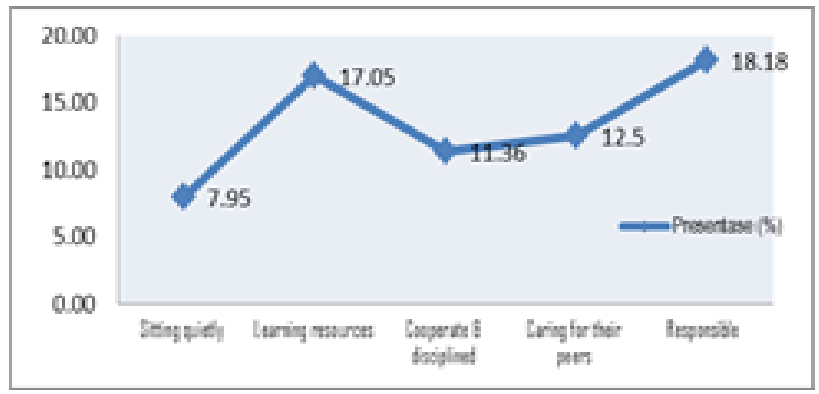

Figure 3. Result of Readiness and Attitudes of Students in Activities

In conclusion, listening skill carried out through on lesson study-based learning activities (LSLC) can attract the attention of students and help focus on playing activities in group B1 Telkom Preschool. In this lesson study activity, the ability to listen with children using storytelling activities is also adjusted to the themes discussed at each meeting according to the children's interests and the development of children aged 5-6. Likewise, when the model teacher did question and answer activities to children about 'experiences to the market' and 'fruits and vegetables', the children appeared to be able to provide various responses and comments. It also raises curiosity to learn in coloring vegetable pictures, decorating pencil cases and kolase activity in group until the lesson ends, The confidence to answer or tell the experience of going to the market in front of the class and want to listen and pay attention to other people who are speak (Wahyuni, 2020; Gayatri et al., 2015; Prasiwi, 2018). Thus, it can be concluded some students have reached the standard in receptive language assessed by the indicator of early listening skill based on lesson study activity. However, some others still need more time and assistance from the teacher to stimulate more improvement and development of their language skill acquisition.

\section{CONCLUSION}

This study concluded that the results children listening skill on lesson study- based learning activity on the 'market day' topic implemented at Telkom Preschool Group B1 in Ternate were categorized good (81.8) and sufficient (68.2). Additional information from this research is that listening ability on lesson study-based learning activities can attract the attention of kindergarten students and help them to focus on playing activities in Telkom Preschool group B1 Ternate.

\section{ACKNOWLEDGEMENT}

The author would like to thank to The Institution of Research and Community Services (LPPM) Universitas Khairun and Telkom Preschool Ternate for their support.

\section{REFERENCES}

Aliah, T. (2014). Lesson Study Sebagai Upaya Peningkatan Profesionalisme Guru PAI Di SMP Negeri 1 Kramatwatu Serang-Banten. 1-81.

Budyawati, L. P. I., \& Hartanto, W. (2017). Implementasi Metode Bermain Peran Untuk

Peningkatan Kemampuan Menyimak Anak Usia Dini Di Paud Sekarwangi Desa Bangorejo Banyuwangi 2017. Jurnal Pendidikan Ekonomi: Jurnal Ilmiah Ilmu Pendidikan, Ilmu Ekonomi Dan Ilmu Sosial, 11(2), 24. https:// doi.org/10.19184/jpe.v11i2.6331

Chong, W. H., \& Kong, C. A. (2012). Teacher collaborative learning and teacher self-efficacy:

The case of lesson study. In Journal of Experimental Education. https:// doi.org/10.1080/00220973.2011.596854

Collaborative for Academic Social and Emotional Learning. (2019). What is SEL? Casel. 
DOI: 10.31004/obsesi.v6i3.1895

Fujie, Y. (2019). Lesson study. In Education in the Asia-Pacific Region. https://doi.org/10.1007/978-981-13-2632-5_7

Gayatri, Y., Ratnadewi, D., \& Ainy, C. (2015). Peningkatan Budaya Kolaborasi Dan Kolegialitas. 15(2).

Gilakjani, A. P., \& Ahmadi, M. R. (2011). A Study of Factors Affecting EFL Learners' English Listening Comprehension and the Strategies for Improvement. Journal of Language Teaching and Research. https:// doi.org/10.4304/jltr.2.5.977-988

Hamann, K., Warneken, F., Greenberg, J. R., \& Tomasello, M. (2011). Collaboration encourages equal sharing in children but not in chimpanzees. Nature. https://doi.org/10.1038/nature10278

Hourcade, J. P., Bederson, B. B., Druin, A., \& Taxén, G. (2002). KidPad: Collaborative storytelling for children. Conference on Human Factors in Computing Systems Proceedings. https:// doi.org/10.1145/506443.506449

Huberman, A., \& Miles, M. (2012). Understanding and Validity in Qualitative Research. In The Qualitative Researcher's Companion. https://doi.org/10.4135/9781412986274.n2

Miharja, F. J., Nurwidodo, N., Wahyuningrum, L., Iffah, A. H., \& Eskasasnanda, I. D. P. (2020). Tokkatsu: Initiating students' collaborative activities in lesson study piloting school. Jurnal Pendidikan Progresif, 10(1), 63-72. https://doi.org/10.23960/jpp.v10.i1.202008

Miles, M. B., Huberman, M. a, \& Saldana, J. (2014). Drawing and Verying Conclusions. Qualitative Data Analysis: A Methods Sourcebook.

Oduolowu, E., \& Oluwakemi, E. (2014). Effect of Storytelling on Listening Skills of Primary One Pupil in Ibadan North Local Government Area of Oyo State, Nigeria. International Journey of Humanities and Social Science.

Pebriana, U., \& Fantiro, F. A. (2017). Peningkatan Keterampilan Menyimak Melalui Model Pembelajaran Artikulasi Dan Media Boneka Tangan Pada Pembelajaran Tematik Kelas 1 Sdn Pejok Ii Kedungadem Bojonegoro. Jurnal Pemikiran Dan Pengembangan Sekolah Dasar (JP2SD), 5(2), 766. https:// doi.org/10.22219/jp2sd.vol5.no2.766-772

Piştav-Akmeşe, P., Sezgin, D., \& Ögüut, F. (2019). Investigation of early literacy skills in preschool children with deaf and hard of hearing. International Electronic Journal of Elementary Education, 12(2), 137-143. https:/ / doi.org/10.26822/iejee.2019257659

Prasiwi, A. A. (2018). Meningkatkan Kemampuan Menyimak melalui Metode Bercerita pada Anak Usia Dini. Paedagogie, 13(2), 43-50. https://doi.org/10.31603/paedagogie.v13i2.2363

Reddy, L. A., \& Reddy, L. A. (2011). II. Group play skill sequences. In Group play interventions for children: Strategies for teaching prosocial skills. https://doi.org/10.1037/13093$\underline{006}$

Samad, F., Pasongli, H., \& Salasa, M. (2020). Caring Community in Early Childhood Learning on Theme "Profession" Based on Lesson Study Activity. Sriwijaya International Journal of Lesson Study, 1(1), 19-24. https:// doi.org/10.36706/sij-ls.v1i1.5

Skills, L. (2009). Developing Early Listening Skills Developing early listening skills.

Spilt, J. L., Koomen, H. M. Y., \& Harrison, L. J. (2015). Language development in the early school years: The importance of close relationships with teachers. Developmental Psychology. https:// doi.org/10.1037/a0038540

Wahyuni, I. (2020). Fostering First Language Skills Through Early Listening Activities: a Case Study on a Pre-School Child'S Language Acquisition. Research and Innovation in Language Learning, 3(1), 57-70. https://doi.org/10.33603/rill.v3i1.3040

Wismath, S. L., \& Orr, D. (2015). Collaborative Learning in Problem Solving: A Case Study in Metacognitive Learning. The Canadian Journal for the Scholarship of Teaching and Learning. https://doi.org/10.5206/cjsotl-rcacea.2015.3.10 